\title{
Food Sovereignty and the Global South
}

\author{
Cristian Timmermann and Georges F. Félix \\ cristian.timmermann@gmail.com
}

This is a "pre-print" accepted manuscript, which has been published in:

"Encyclopedia of Food and Agricultural Ethics"

This version is distributed under the Creative Commons Attribution 3.0 Netherlands License, which permits unrestricted use, distribution, and reproduction, in any medium, provided the original work is properly cited.

Please cite this publication as follows:

Timmermann, Cristian and Georges F. Félix (2016), Food Sovereignity and the Global South. In: Encyclopedia of Food and Agricultural Ethics, 2nd edition, edited by Paul B. Thompson and David Kaplan, Dordrecht: Springer.

The final publication is available at Springer via:

https://doi.org/10.1007/978-94-007-6167-4 524-1 


\title{
Food Sovereignty and the Global South
}

\author{
Cristian Timmermann \\ Instituto de Investigaciones Filosóficas \\ Universidad Nacional Autónoma de México \\ Ciudad de México, Mexico \\ cristian.timmermann@gmail.com \\ and \\ Georges F. Félix \\ Farming Systems Ecology \\ Wageningen University \\ Wageningen, The Netherlands \\ georges.felix@wur.nl
}

Synonyms: self-determination and food policy; autonomy and food production; food self-sufficiency; agriculture in the developing world and transition economies.

\section{Introduction}

Farmers' organizations all over the world are very well aware that in order to build and retain a critical mass with sufficient bargaining power to democratically influence local governments and international organizations they will have to unite by identifying common goals and setting aside their differences. After decades of local movements and struggles, farmers' organizations around the globe found in the concept of "food sovereignty" the normative framework they were long searching for. The broadness of the concept has had a remarkable success in embracing the interests of food producers and consumers from all geographic locations and development levels.

Having identified the common concept, farmers' organizations started to debate the normative implications the idea of food sovereignty brings about. The most prominent fruit of such deliberations is the declaration on "The right to produce and access land" proposed by the farmers' organization Vía Campesina in Rome 1996. That year food sovereignty was defined as "the right of each nation to maintain and develop its own capacity to produce its basic foods respecting cultural and productive diversity" (Via Campesina 1996). Eliminating hunger through an authentic agrarian reform and giving farming families a larger role in the development of food trade policies are some of the main demands set in the declaration of 1996.

The concept should not be interpreted as static, as it is continuously evolving to adapt to farming societies' new challenges and needs across latitudes (Agarwal 2014). We will proceed by examining the different demands set in the 1996 declaration and analyse their implications for the Global South by discussing additional insights of later meetings such as the Declaration of Atitlán held 2002 in Guatemala and the Nyéléni Forum for Food Sovereignty held 2007 in Mali.

\section{Food sovereignty: a list of demands}


Demands of smallholder farmers across the world to increase food self-sufficiency go hand in hand with local advocacy for supportive food, agriculture, and trade policies. Thus, in the first declaration we can identify eleven demands (Via Campesina 1996):

(1) A right to access food that is safe, nutritious and culturally appropriate in sufficient quantity and quality to sustain a healthy life in dignity

(2) A right to define agricultural and food policies (i.e. self-determination)

(3) A right to practice ecologically and socially sustainable management of natural resources that allows preserving biological diversity

(4) A right to prioritize local food production

(5) A right to protect against dumping and "too cheap" products, including price controls and taxation to safeguard local production

(6) A right to establish policies to facilitate access essential for food production to (i) productive land, (ii) credits, (iii) technology, (iv) markets and (v) extension services

(7) A right to regulate and tax speculation with food products

(8) A right to be free from violence

(9) A demand for more recognition for the value of agricultural labour

(10) A demand for recognition of women's role and contribution to food security

(11) A demand for a long-term societal commitment to make rural infrastructure socially and ecologically appropriate (i.e. rural development)

Later deliberations (Consulta de los Pueblos Indígenas sobre el Derecho a la Alimentación 2002; Nyéléni Forum for Food Sovereignty 2007) have also specified the recognition of:

(12) A right to produce food

(13) A consumer's right to choose (i) what to buy, (ii) how food is to be produced and (iii) whom to buy from (i.e. consumer sovereignty)

(14) A right to control food production in order to avoid waste and other forms of over production

(15) A right to access (i) water and (ii) seeds

(16) A right to prohibit the introduction of genetically modified organisms in agricultural lands and food markets

To bundle up, these demands concentrate around four central elements: access to the means of production, self-determination, recognition, and limiting unfair competition and intervention. These demands are not realizable if farmers themselves do not make a commitment to recognize each other's - including women's - efforts and role in food production and trade.

Let us analyse some of the challenges encountered in the Global South to implement the idea of food sovereignty.

\section{Main challenges to achieve food sovereignty in the Global South}

A central problem for the success of the food sovereignty movement is to develop a capacity to build and retain critical mass to be able to advance policies that promote common interests. This is however a very difficult task as there are a variety of 
competing movements with similar targets (Hospes 2014) and well-established powerful private interests groups who benefit enormously if farmer organizations remain fragmented. Among the groups fighting for a similar cause we can find people from United Nations organizations who try to secure access to food using the human rights language, especially the right to food discourse (De Schutter 2011). Another group prefers recalling principles of commutative justice by fighting for decent remuneration and work conditions relying on fair trade principles (Raynolds 2014). A further group also works with the justice discourse, but argues that food justice needs to go beyond focusing on fair transactions and include environmental sustainability, democratic decision-making, safe work environments and access to healthy food (Food Ethics Council 2010). While the different groups tend to agree on the most important goals - accessibility and availability of food, decent farm work conditions and ecological sustainability - they disagree on the strategic discourse to achieve these aims. We should not understate the power major multinational corporations and political parties with neoliberal trade policies have to influence the discourse, and especially in the Global South, to assert licit and illicit pressure on farmers' organizations. Here the old Roman saying - divide et impera - best describes the opportunity for corporations and neoliberal governments, and the vulnerability of farmers' organizations.

The food sovereignty movement in the Global South has the added difficulty that farmers count an extremely large number of people with varying priorities and opportunities. These farmers and their families face huge collective action problems as a group, and have together and individually little disposable income to organize their interests. Multinational corporations who want to introduce their products in local markets and governments seeking to attract foreign investments have a much more structured agenda and have much more income at their disposal to organize campaigns to change public opinion to their advantage (Ziegler 2011). States as sovereigns have also the authority to sign large-scale long-term land lease agreements and dictate agricultural policy. In comparison, individual farmers have repeatedly the temptation to deviate their actions from collective interests, as they often can improve their odds or avoid risks by free-riding from collective efforts. The need for disposable income increases this temptation, as farmers, like anyone else, are embedded in a social context where they face social pressures and demands as diverse as school materials for kids and fashionable clothing for the youth.

Farmers in the Global South also recognize that they have a major problem with inadequate training (Nyéléni Forum for Food Sovereignty 2007). Capacity building is needed to improve the organization, advocacy and deliberation capabilities of farmers' organizations, to build new food retail channels, to recover traditional farming techniques and to learn and improve agroecological farming methods. There is also a strong demand that information on agricultural and food policy, technological risks and trade agreements be made transparent, precise and understandable for a wider audience (Consulta de los Pueblos Indígenas sobre el Derecho a la Alimentación 2002). Implicit is the demand that documents should not contain a massive amount of redundant details that makes careful screening prohibitively expensive for smaller organizations, as we can observe with several trade agreements.

There is still a major research effort needed to meet the demands for ecological sustainability, even more, if we take into consideration the rapid migration to urban areas within Global South. Intensification of ecological processes in agriculture is to be based on achieving local yield potentials, enhancing soil quality parameters, and integrate precision agriculture schemes that value both technological advances and 
farmer knowledge (Tittonell \& Giller 2013). Yield potential can be reached through proper diagnostics of farming system issues and re-design of the systems taking into account locally available biological diversity as well as farming families' aspirations. Soil quality needs adequate land management that prevents topsoil erosion, promoting physical, chemical, and biological parameters to express fully. Whether with use of GPS-guided tractors or farmers' knowledge of the landscape, by engaging into a precise form of agriculture it is possible to assess and remedy site-specific situations that undermine yield and soil potentials.

Important to note is that shifts towards food sovereignty and ecological sustainability will clash with feasibility constraints unless major efforts to adapt agriculture to growing urbanization are made (Bernstein 2014). There are, however, a number of current initiatives and projects to grow more food in cities, such as aquaponics (a combination of aquaculture and hydroponics), roof gardens, vertical farms, allotment (community) gardens and towers for animal production. Cuba, for example, has shown a remarkable success in instituting ecological urban agriculture by transforming underused lots in community gardens (Altieri et al. 1999). Despite technological advances, ecological sustainability still has the constraint that we as humanity need to identify and respect the balances we have to maintain with nature and see how we can align these with the dynamic needs of a continuously changing society. Food sovereignty therefore not only requires scientific and technological advances, but also social and ethical innovations.

Aside from collective action problems, in many societies around the globe there is still a huge deficit and lack of will to address issues of gender inequality (Agarwal 2014). The various declarations of food sovereignty acknowledge the essential role women play in food production and preparation, and demand recognition for their effort. There is a strong need to abolish discriminatory laws for divorce and inheritances, especially as these laws jeopardize access to land for women (Nyéléni Forum for Food Sovereignty 2007). It will be a major challenge to ensure proper recognition and gender equality in societies characterized for embracing patriarchal principles, as it will require that people let go from some deeply-anchored traditions.

There is an urgent need to address the health challenges current food systems are having on people in both the Global North and Global South. Especially poor people in transition economies have acquired eating habits that are detrimental to their health. Fresh fruits and vegetables are in urban areas often more expensive than food rich in saturated fats, salt and sugars. As children tend to acquire the same eating habits as their parents, poor eating habits are passed on from one generation to the other, and so also the vulnerabilities and financial burdens of non-communicable diseases malnutrition leads to. Society ends up paying triple for such bad food policies. People pay for wrongly set subsidies that encourage the production of staple foods, for the advertisement costs of processed food and for the public health costs of malnutrition (De Schutter 2011). Hunger and diets that do not offer the minimum doses of vitamins and minerals are still endemic in the poorest regions of the world. Here we should note that it is vital to ensure proper nutrition between pregnancy and the end of the second birth-year, as malnutrition may lead to permanent damages in the child's development (Ziegler 2011).

A problem for the food sovereignty movement is that local food is not necessarily healthy and consumers do not make continuously healthy food choices. As much autonomy and consumption of local food may be involved in a gaucho's preference for free range Patagonian meat, a Mexican's craving for tacos dorados or an Antillean's appetite for a deep fried plantain dish, if these food choices become 
habitual, someone will have to assume the tasks of informing consumers that these dishes form an unhealthy diet. Similarly, traditional dishes that are a constitutive element of a people's heritage are not always healthy either. Supplying the ingredients for such dishes for current population levels may also not be ecologically and socially sustainable anymore. The sustainability demands set forth in food sovereignty may request that people adapt their diets by including food products that are foreign but can be produced with less environmental impact and avoid traditional dishes that demand products that cannot be grown or catch in sufficient numbers in a sustainable manner in today's world. In many regions of the world this means: reduce meat consumption and eat more frequently a variety of pulses. The simplicity of this rough statement stands deeply at odds with current shifts within the food system. Over the last decades the food chain has been changing from a supply system to a demand system (Korthals 2001). Food sovereignty and consumer sovereignty can only co-exist if consumers learn to make sustainable food choices and prevent food waste by absorbing eventual seasonal oversupplies.

Alarming from a social and environmental perspective is the extensiveness of land areas that are untouched by a rule of law that the least faintly adheres to human rights principles. Such areas often employ a massive number of people of all ages who work as slaves or in conditions similar to slavery, adding to millions worldwide. Drug cartels and sympathizing local governments have caused massive displacements of people who are usually thriven to poverty as they lose their land and often suffered physical and psychological damages that impede them to live normal lives. The unregulated cultivation of opium poppies, cannabis, and coca bushes in a number of countries of the Global South - in particular Afghanistan, Myanmar, Mexico and Peru - is becoming so extensive that it causes major disruptions in food security and the ability for governments to regulate the use of environmentally sound agricultural inputs. To gather an idea of the magnitude of such plantations, we can refer to Afghanistan's cultivation of 220'000 hectares of opium poppy, Peru cultivated illicitly about 49'000 hectares of coca bush and Colombia farmed roughly the same surface (United Nations Office for Drugs and Crime 2015). Mexico and Afghanistan reported massive cultivation of multiple illicit crops (idem). Large-scale police and military action is devoted to continuously destroy such plantations. To recover losses drug cartels continuously clear new land areas, provoking anew the displacement of people and the destruction of nature.

Access to land for food production is also constrained by individual farming choices and changes in profession of farmers' children. Many smallholders are now farming cash crops, such as cotton, and encourage their children to opt for other professions (Agarwal 2014). Rural populations age as the youth move to apparently more lucrative endeavours such as mining, or try their odds in the big cities. A major challenge for food sovereignty will be to stimulate a new generation of young people to choose to work the land. As a measure to achieve this goal, farm work quality needs to be significantly improved by increasing autonomy, encouraging experimentation and building better farmers' knowledge exchange networks (Timmermann \& Félix 2015).

Criticisms on the concept of food sovereignty concentrate on issues of feasibility in a world that has accepted free trade principles and a lack of consensus and specification on the underlying concept of sovereignty (Hospes 2014). Farmers around the globe still have to agree on the concept of sovereignty. At which level should decisions be made? State, region, township or peoples? This is a very important issue in the Global South, as borderlines of a large number of countries where drawn by colonial powers without regard of ethnic groups and geographic terrains thus making it 
difficult to draw adequate common policies. At the moment there seems to be a consensus on people's food sovereignty (Agarwal 2014). We will have to wait for the future to see how these demands can be implemented in and across local governments.

\section{Future outlook}

As a conclusion, we are to examine the major future challenges for food sovereignty in the Global South. A factor that is already a problem and for which no solution appears in the horizon is extreme inequality. People who suffer deprivation are much more vulnerable to be exploited by those who have more financial resources and power. The poor are more likely to lose their land and to offer their labour for miserable wages. Governments who desperately need foreign investment are more willing to sign largescale land leases. Such deals often result in a shift of agricultural production from food to biofuels (Ziegler 2011). Extreme inequality also makes it easier for powerful groups to illicitly influence political decision-making for their own advantage at the cost of the poor thus weakening states. And states that are or become weak are much more vulnerable to military coups and less able to control drug cartels.

An additional problem for future food production is climate change, which will have its harshest effects in countries of the Global South. These countries face already the highest hunger burden and have the smallest budgets to adapt agriculture to upcoming environmental changes.

These problems will put an enormous pressure on the food system and will raise a strong social demand to make the most efficient use of land. As land is a limited resource, farmers will face an increased difficulty in sovereignly deciding on agricultural practices.

\section{Cross-References}

$\rightarrow$ Access to Food

$\rightarrow$ Access to Land and the Right to Food

$\rightarrow$ Food Democracy in Food Systems

$\rightarrow$ Food Deserts

$\rightarrow$ Food Sovereignty

$\rightarrow$ Food Sovereignty and Agri-business

$\rightarrow$ Gender Inequality and Food Security

$\rightarrow$ La Via Campesina

\section{References}

Agarwal, B. (2014). Food sovereignty, food security and democratic choice: Critical contradictions, difficult conciliations. Journal of Peasant Studies, 41(6), 1247-1268.

Altieri, M. A., Companioni, N., Cañizares, K., Murphy, C., Rosset, P., Bourque, M., \& Nicholls, C. I. (1999). The greening of the "barrios": urban agriculture for food security in Cuba. Agriculture and Human Values, 16(2), 131-140. 
Bernstein, H. (2014). Food sovereignty via the 'peasant way': a sceptical view. Journal of Peasant Studies, 41(6), 1031-1063. doi: 10.1080/03066150.2013.852082

Consulta de los Pueblos Indígenas sobre el Derecho a la Alimentación. (2002). Declaración de Atitlán. Panajachel.

De Schutter, 0. (2011). The right to an adequate diet: The agriculture-food-health nexus. Geneva: United Nations.

Food Ethics Council. (2010). Food Justice: the report of the Food and Fairness Inquiry. Brighton: Food Ethics Council.

Hospes, O. (2014). Food sovereignty: the debate, the deadlock, and a suggested detour. Agriculture and Human Values, 31(1), 119-130.

Korthals, M. (2001). Taking consumers seriously: Two concepts of consumer sovereignty. Journal of Agricultural and Environmental Ethics, 14(2), 201215.

Nyéléni Forum for Food Sovereignty. (2007). Declaration of Nyéléni. Sélingue: Nyéléni Forum for Food Sovereignty.

Raynolds, L. T. (2014). Fairtrade, certification, and labor: global and local tensions in improving conditions for agricultural workers. Agriculture and Human Values, 31(3), 499-511. doi: 10.1007/s10460-014-9506-6

Timmermann, C., \& Félix, G. F. (2015). Agroecology as a vehicle for contributive justice. Agriculture and Human Values, 32(3), 523-538.

Tittonell, P., \& Giller, K. E. (2013). When yield gaps are poverty traps: the paradigm of ecological intensification in African smallholder agriculture. Field Crops Research, 143, 76-90.

United Nations Office for Drugs and Crime. (2015). World Drug Report 2015. New York: United Nations.

Via Campesina. (1996). The right to produce and access land. Rome: Via Campesina.

Ziegler, J. (2011). Destruction massive: Géopolitique de la faim. Paris: Seuil. 